\title{
School Management Teams' Conceptualisation of School Assets in Addressing the Needs of Children Orphaned and Made Vulnerable by HIV and AIDS: Evidence from South Africa
}

\author{
Vitallis Chikoko ${ }^{1}$ and Fumane Khanare ${ }^{2}$ \\ School of Education and Development, Faculty of Education, University of KwaZulu-Natal \\ $P$ Bag X 03, Ashwood 3605, South Africa \\ Email: <chikokov@ukzn.ac.za>, ${ }^{2}<$ Khanare@ukzn.ac.za>
}

KEYWORDS Assets. Collage.School Management Team.Orphans. Rural

\begin{abstract}
This paper explores School Management Teams' understanding of school assets as a means to respond to the needs of orphans and other children made vulnerable by AIDS in the context of rural schools in South Africa. The study employed a qualitative approach of data collection, using an art-based method, that is, collage to identify the School Management Teams' responses to the needs of children orphaned and made vulnerable by AIDS in a rural school context, which included their identification of assets (resources) within and outside the school context, and concerns about the mobilization and mapping out of assets using a collage. The School Management Teams' understanding of assets included material things such as food and clothes. The findings also show that School Management Teams relied more on outside assets than assets within the school. However, with the use of the collage, as a means to chart their way forward, School Management Teams engaged in a discussion and looked at the extent to which learners, teachers, School Management Teams, School Governing Bodies and outside community assets such as faith-based organisations, businesses and parents could be mobilized and mapped in order to effectively respond to the needs of orphans and other children made vulnerable by AIDS in a rural context.
\end{abstract}

\section{INTRODUCTION}

An estimated 14 million children below the age of 18 have been orphaned by AIDS in subSaharan Africa (UNAIDS 2009). South Africa is no exception with approximately two million children being orphaned by AIDS (UNAIDS 2010a). Many other children have become vulnerable due to HIV and AIDS. Most of these are schoolgoing children. Drawing from a study the researchers conducted in two rural high schools, this paper seeks to achieve a two-pronged goal: to examine how the School Management Teams understood assets in the process of supporting children orphaned and made vulnerable by AIDS; and to explore the possibility of utilising collage as a visual participatory method to achieve the same supportive goal. South Africa has declared that schools shall cater for $A L L$ children (Department of Basic Education and MIET Africa 2010; UNICEF 2009; Department of Education 2003). In the context of South Africa's decentralised system of education, the School Management Team has become the central decisionmaking structure in every public school. With the world being bogged down by what is termed education in the age of HIV and AIDS, the nature and role of a school is fundamentally chang- ing. There is a significant amount of literature about schools as centres of information and support for the communities they serve (Kendall 2007; Kendall and O'Gara 2007; Van Wyk and Lemmer 2007; Argall and Allemano 2009; Department of Basic Education and MIET Africa 2010; Williams 2010).

The researchers conducted this study in South Africa's KwaZulu-Natal, a province with a high HIV and AIDS prevalence rate. While evidence suggests that the prevalence of HIV for the last three years in the country has shown some stability, there are variations among provinces. For example, the Western Cape reported the lowest estimate of $16.1 \%$, while KwaZuluNatal had the highest at $38.7 \%$ in 2009 (UNAIDS 2010a). Vulindlela, our target district had the highest percentage of HIV cases in the province at 37\% (Abdool-Karim 2006).

South Africa has large numbers of rural schools situated in various provinces around the country. The very isolation of the rural space makes for the intensity of the lived experiences (Balfour et al. 2008). Such lived experiences tend to be more intense for vulnerable learners in the context of HIV and AIDS. Usually, rural communities lack financial resources and have to survive with limited resources. Therefore doing this study in a rural context was most appropriate to 
identify the existing resources in a rural school but also how these resources could be mapped to respond to the needs of orphans and other children made vulnerable by AIDS. We chose two rural schools as priority, not in terms of their short economic factors, but as a context where participation of everybody is essential. The researchers have been in good continuous connection with the educators, deputy principal and principal of the selected schools as some of our colleagues from the University of KwaZulu-Natal run different projects in schools in Vulindlela.

\section{The State of Orphans and other Children made Vulnerable by AIDS in Rural School Context: A Snapshot}

The majority of orphaned and vulnerable children continue to live (spend more of their time) in the care and support of the schools. The UNAIDS (2010b) report reveals that in most countries in sub-Saharan Africa, there is a considerable increase in school attendance by orphaned and vulnerable children. Despite this, orphaned and vulnerable children particularly those from rural poor communities have their schooling interrupted. Failure to secure school uniforms, shortage of food and isolation often present barriers to their school attendance. Even with the expansion of 'no fees' programmes, many responses for orphaned and vulnerable children remain small-scale and fragmented. It is estimated that by 2015 the number of orphaned and vulnerable children will still be overwhelmingly high (UNAIDS 2008). The breadth and depth of the challenges of rural schools are likely to continue. Persistent poverty due to unemployment, long distances between home, schools, clinics, and police stations are not romantic, but harsh realities in rural environments that negatively impact on the care and support of orphaned and vulnerable children. Too often, however, poverty is not just about the absence of income, it is about isolation, being overlooked, and/or ignorance. It is also about disempowerment of school leadership and lack of agency which hold back full participation of rural people. A significant factor for a school to succeed in care and support of orphaned and vulnerable children is to understand better, the notion of rurality as a lived experience over time and place.

\section{Understanding'Rurality’}

Children in rural contexts of South Africa seem to be more vulnerable than others elsewhere. In South Africa, rurality is a multi-layered concept encompassing the farming communities, peri-urban settings, informal settlements, and what is often referred to as the 'deep rural' (Gabela 2006). 'Deep rural' is a popular term referring to some of the remotest parts of the countryside (Chikoko 2008). The term 'rural area' is often used as a synonym of 'remote area' (Pansiri 2008). Pansiri further characterises a remote area as one that is informationally and infrastructurally underdeveloped with the people therein being marginalised from the socio-politico-economic activities run from the centre. In addition, rural communities are often in the periphery of society's mainstream activities due to factors such as low levels of education of the majority of the adults, limited economic empowerment opportunities, and lack of civic knowledge such as human rights. Rural schools as part of such communities would therefore be equally marginalised and disadvantaged and therefore many learners therein being vulnerable. While the researchers would not characterise the two schools whose School Management Teams were studied as being located in one of the remotest parts of the country, they are certainly in a remote area with many vulnerable children.

This above characterisation of rurality denotes a deficit model which views a community as totally incapable of addressing its own problems and therefore at the mercy of external intervention. In this paper, while the researchers appreciate the reality of this characterisation, particularly as South Africa is still recovering from the ravages of apartheid, they argue for the asset model (Kretzmann and McKnight 1993). In this connection, Chikoko (2008: 77) has the following to say:

While rural communities are often characterised by a cocktail of social ills (disease, poverty, low levels of education, limited facilities, etc.) that bedevil these parts of the South African society, and by the apparent 'emptiness', and therefore needing urgent external intervention, we should not lose sight of the hidden [but very present] resources[assets] that these communities are endowed with. 


\section{Understanding 'Assets'}

The researchers use the term 'assets' in this paper to signify all resources, actions, transactions, capacities, abilities, inner strengths, possessions and so on that people have but not yet fully realised. Assets imply also a basic understanding of the necessity to coordinate resources in a sustainable way. Therefore assets are both material and non-material.

The major blind spots in the prevailing school context (particularly schools in rural area) thinking seem to be:

- Mapping Assets: This means to identify the initial list of potential participants and incorporate as many partners as possible from inside and outside the immediate environment (Khanare 2008). It is important to note that the focus on existing assets particularly in poor communities does not imply that additional resources are no longer needed.

- Mobilising Assets: This entails providing continuous support by reallocating available or attainable resources so that innovations do not deplete resources needed by other initiatives in the school system (AlBarwani and Osman 2011: 849).

These two constituents are either misconceived or ignored, yet they are very basic from the point of view of a sustainable way of supporting orphans and other children made vulnerable by AIDS.

\section{The Place of the School Management Team in a South African School}

South Africa runs a decentralised system of schooling in which schools have been granted the authority to make many decisions regarding their own affairs in such areas as finance, human resources, school development, etc. The School Management Team, made up of the principal, the deputy principal and Heads of Department is the highest executive decision-making structure in the school. The nomenclature 'School Management Team' is a bit misleading in that it suggests that this body only performs a management function and yet it is expected to equally play a leadership role. The two terms are elusive in that "there is no clear-cut division between management and leadership, and yet their features are distinct. There is no "either-or" but an "as well as" (Schley and Schratz 2011: 276).

The importance of the School Management Team's role can be illustrated by how Hinterhuber (2003) quoted by Schley and Schratz (2011: 277) shows the complementary nature of leadership and management as shown in Table 1.

Due to this interrelation between management and leadership, the researchers shall, in this paper refer to 'leadership' or 'school leadership' to mean both concepts. One of the critical priorities for schools set out by the South African National Department of Education is that the school community is expected to work together and manage a joint response to ensure quality education for all learners (Department of Basic Education 1996). Such working together requires the leadership capacities illustrated in Table 1. In addressing the issues of orphaned and vulnerable children, efforts need to be harnessed and combined in a collaborative manner (Khanare 2009). The leadership role of the School Management Team becomes very important in engaging with the national policies and in mobilising and mapping assets and carrying out strategies to deal with the needs of orphans and other children made vulnerable by AIDS.

Table 1: Interrelation between management and leadership (Adapted from Hinterhuber 2003) in Schley and Schratz 2011: 277).

\begin{tabular}{ll}
\hline \multicolumn{1}{c}{ Management } & Leadership \\
\hline Creative problem solving & $\begin{array}{l}\text { Discovering new possibilities with the capacity to real } \\
\text { ize them or make them realized } \\
\text { Creating a new paradigm }\end{array}$ \\
$\begin{array}{l}\text { Working within a paradigm } \\
\text { Working within the system }\end{array}$ & $\begin{array}{l}\text { Working on the system } \\
\text { Getting "things" and people into motion, } \\
\text { methods, techniques, control }\end{array}$ \\
$\begin{array}{l}\text { mances and empowering staff to achieve top perfor- } \\
\text { The human being as support (aid) } \\
\text { Attitude of "doing" }\end{array}$ & $\begin{array}{l}\text { Dignity for the human being (trust) } \\
\text { Attitude of "serving" }\end{array}$ \\
\hline
\end{tabular}




\section{Towards an Asset-based Approach}

In explaining the asset-based approach, Ebersohn and Eloff (2006) refer to the strengths that can be identified, accessed, mobilised and sustained in order to address scarcity/problems/ shortcomings and/ or challenges. Contrary to the needs-based approach, which emphasises deficiencies within a system and therefore pointing at the need for an externally-driven remedy, the asset-based model seeks to identify strengths, abilities, capacities of individuals, groups and contexts in order to overcome the deficiencies. Even in rural contexts, there are resources/assets that can be identified in order to respond to the needs of orphans and other children made vulnerable by AIDS (Khanare 2009). In recent years the researchers have witnessed an increase in the literature that advocates the involving and empowering of individuals and their contexts. As Ebersohn and Eloff (2006) rightly argue, much time and effort has been spent on thinking of needs and problems but recently the focus is shifting towards finding solutions and by working with existing strengths, assets and capacities. For Kretzmann and McKnight (1993) all individuals, families and communities have capacities, skills, resources and assets that they can develop to become people who are able to solve problems in a variety of contexts. This approach therefore stresses that even in the poorest schools, even in rural areas there exist some assets that could be explored, created and made best use of in the communities in question. Therefore the importance of knowledge to map, mobilise and include all stakeholders for what they know and are able to do cannot be over-emphasised (Khanare 2009).

In this paper the researchers' notion of care and support for orphaned and vulnerable children is therefore informed by the shift from 'deficit thinking' or seeing schools especially in rural contexts as lacking, to asset-based thinking involving identifying existing resources available to the school and bringing these to bear in addressing problems therein. As people mobilise cultural, physical and other assets at their disposal, they become active problem solvers rather than passive clients of the society in which they belong (Kretzmann and McKnight 1993). In a school context, the School Management Team members become stewards to include all stakeholders and open access to information. School leaders such as the principal are called upon to lead the processes of engaging others and sharing responsibilities and expertise in carrying out strategies to care and support orphans and other children made vulnerable by AIDS in the school contexts (Buthelezi 2008). As rightly argued by Khanare (2008) a well-coordinated and integrated approach is very important in this regard. An understanding of school assets is important for the development of social relationships and the establishment of links across cultural resources to respond successfully to the issues of orphans and other children made vulnerable by AIDS.

\section{Research Questions}

The study was driven by the following two critical questions:

- How do the School Management Teams understand assets in the context of addressing the needs of orphans and other children made vulnerable by AIDS?

- Can collage as a visual participatory approach be utilised to assist the School Management Teams to understand assets in response to orphaned and vulnerable children in a rural school context?

\section{METHODOLOGY}

\section{Collage as a Participatory Visual Methodology}

This study adopted a qualitative approach to examine and analyse, through collage, School Management Teams' understanding of assets in the context of addressing the needs of orphaned and vulnerable children. Studies by visual sociologists (Becker 1974; Goffman 1979; Wagner 1979; Collier and Collier 1986) initiated a paradigm shift from the conventional way of undertaking research to a more 'seeing' and ultimately 'perceiving' form of visual sociology (Prosser 1998). More recently, Fargas-Malet et al. (2010) also highlighted the emergence of new participatory research methodologies. They argue that this shift has come about as result of the need to allow indigenous and minority populations to take care over their lives (FargasMalet et al. 2010). Sullivan (2010) contends that visual participatory methodologies provide a sense of enjoyment in the research activities, 
that participants learn visual skills, and more importantly that in the intense and sincere engagement of the participants while learning to produce the visual artefacts, for example pictures and texts, they choose what they want to talk about, which experiences are important to them, and so have a space to think about and reflect on their own lives. This engagement could contribute to subtle change in their lives. The energy and creativity of people, especially those living in less resourced environments such as rural school contexts, (Fargas-Malet et al. 2010) to explore issues related to HIV and AIDS cannot be underestimated. Visual participatory methodologies have been reported as capable of offering a nested approach to research as a forum for sharing and voicing experiences (Olivier et al. 2007; Park et al. 2007; Balfour et al. 2008). For this reason, the researchers were keen to draw on collage as a participatory methodology with the School Management Teams as 'identifiers' and 'mobilisers' of assets or what $\mathrm{Ng}$ ' ango (2011) refers to as collective citizen actors. "Collage is a form of art that involves creating a work from pictures; this may also include words and photographs" (Khanare 2009: 224). It can be very low-tech and the materials used in a collage can be original, borrowed, or a combination of both, and the medium is limited only to the imagination of the artist. Norris et al. (2007: 43) say the following about collage:

Collage...is a democratic..., it can be used to persuade, explain and critique...It creates action spaces for people to talk, ask questions, disagree, reveal misconception, and so on.

Literature therefore suggests that collage as a visual participatory method, creates space for people to think, put ideas together using pictures and texts. This method is quite suitable for qualitative research because it can be used in many circumstances in a relatively unobtrusive manner and "expand the possibilities of multiple and diverse realities and understandings" (Butler-Kisber 2008: 268). It provides for both the visual and text forms of evidence-a facet often missing in other methods such as interviews. Collage is also argued to create opportunities to learn new skills, such as visual skills, as well as to unlearn beliefs. The researchers therefore chose collage because it can move people from talking to action. On the economic front, collage can be very low in technology, not necessarily needing internet or electricity-threats to most rural schools. It is about being thoughtful and creative. Creativity and thoughtfulness are possible even in the remotest of contexts hence our adoption of this method in a rural setting.

\section{Participants}

As the researchers have already alluded to, School Management Team members from each of the two schools were the participants. In each school there were four School Management Team members: the principal, deputy principal, and two heads of department. Thus a total of eight people participated in the study. As the researchers pointed out earlier, the School Management Team is central to all decision- making in a school, therefore these participants were, as a purposive sample, deemed to be potentially information-rich (Babbie and Mouton 2009) regarding the plight of orphaned and vulnerable children.

\section{On Creating the Collage: Setting the Scene}

Once the necessary permission was acquired, participants were approached to participate in the study. They were assured of complete confidentiality and encouraged to disclose as much valuable information as they possibly could.

The creation of a collage is not just a 'cut and paste' activity (Khanare 2009). Therefore the researchers started with a brief workshop seeking to clarify how the process was to unfold. The researchers gave a short description of a collage. They also brought two students' collages for the School Management Teams to have a look, ask questions, and seek clarifications. They emphasised the importance of being precise and practical regarding how they thought they would address the needs of the orphans and other children made vulnerable by AIDS in their school context. There was a lot of looking, questions, astonishment and laughter'wow', 'huhh' 'ok' moments were notable during this session. They impressed upon the School Management Teams that the whole purpose of this workshop was that the participants as experts of their own lives were capable of showing and telling their own 'stories', and in their telling reflect on their own lived experiences (Mitchell et al. 2007; Olivier et al. 2007; Mudaly and Sookrajh 2008). The researchers also high- 
lighted to them that collage was a useful tool for developing critical dialogue (Thomson 2008). On the other hand, it would give the participants an opportunity to represent experience, a tangible process and product, out of which stories are (re)created.

The researchers then gave the School Management Teams instructions prior to their creation of the collage as follows:

Using a combination of pictures and text from magazines, make a collage showing any resources which are available to you as the school which will help to address the needs of orphans and other children made vulnerable by AIDS in the context of HIV and AIDS, that is:

o What do you think/how do you think you can help these learners?

o Make a collage of how you think the school can help to address the needs of these learners,

o Draw any resources that you think can help you but which you do not find pictures for.

- Share collage: put up on the wall and have a 't/walk about'while everyone views the collages.

\section{Guiding Questions for the School Management Teams}

- What resources are available at the school (both human and material)?

- What resources are available to the school?

- What would you as School Management Team do - if anything - to support/get supported in the school in this age of HIV/ AIDS? (how exactly do you think you will go about connecting or engaging other stakeholders)

- What would be the policy of the school in this case with respect to care and support of vulnerable learners in the school in this age of HIV and AIDS?

The 'doing' aspect of the collage is important to the process. This implies that the School Management Team members were not only asked to identify assets, but crucial to the process was how they would go about mapping and mobilising them in such a way that they became meaningful to the needs of orphans and other children made vulnerable by AIDS. Resource mobilisation, as Al-Barwani and Osman (2011) con- tend, entails providing continuous support by reallocating available and attainable resources so that innovations do not deplete resources...or have negative impact on the school systems. This calls for the School Management Teams to be active and ensure the involvement of all stakeholders while they are recognising the complementary role they play in supporting orphaned and vulnerable children.

\section{Creating the Collage}

Through the experience of creating a collage, the researchers sought to provide the School Management Team members an opportunity to relook and reframe their own identity and that of the school. They aimed at putting the School Management Teams in the position of doers or compilers of pictures, of communication, and of ideas in order to address the needs of orphaned and vulnerable children. As Allnut et al. (2007: 94) note, "the compiler comes to understand the importance of bringing multiple selves... reframe... examine... [issues]", in the context of this study, orphans and other children made vulnerable by AIDS.

Participants were given magazines, glue, coloured pens, scissors and charts as apparatus for creating their collage. As a point of departure towards creating the collage, the researchers offered the following prompts to the School Management Teams:

In trying to address issues of orphaned and vulnerable children in your school, what available resources do you draw on? Make a collage to represent your response. Think about and jot down what you intend to put in the collage. Where possible extract a picture from the given magazines to illustrate your thought and if you cannot get a picture, try to get a text or your own word or drawing. Paste it on your collage.

The School Management Team members could not just 'cut and paste', the prompts provided a space and time for them to page through as many magazines as possible, compare and contrast their choices of pictures and or texts before pasting them, and to think individually and collectively about what, how and why they were or were not addressing the issues of orphaned and vulnerable children in their schools. Taking self or collective evaluative stances, they actively and purposely engaged in debates that were directly related to the issues of their own 
schools. This according to Al-Barwani and Osman (2011) provides opportunities for shared goals and a unified focus. The exercise provided an opportunity for the School Management Teams to 'learn together' (Mitchell et al. 2005) and share directly their reality and capture it visually (Creswell 1994).

After they had done the collage, the researchers then asked the School Management Teams to classify their work into different types of assets according to their own understanding. Assets were classified in terms of their vintage points as 1) material and non- material, 2) providers of those assets (faces and places) and 3) missing assets which according to the School Management Teams could also best represent the solutions to addressing the needs of orphaned and vulnerable children in a school context. During the collage and throughout the discussion proceedings were audio and video-recorded with the participants' permission.

\section{RESULTS AND DISCUSSION}

Identifying assets is a major opportunity to assess the school community's potentials, capabilities, and talents. For example, identifying informal local networks such as other learners, organisations around the school, small businesses etc. could play a critical role in addressing the issues of orphaned and vulnerable children in a school. The use of collage created an opportunity for the School Management Teams to identify and take stock of its potential physical resources in order to muster support for orphaned and vulnerable children. The essence of School Management Teams' understanding of assets has been depicted from the pictures and texts in the collage. From the collage, the School Management Teams identified various levels from which they could draw in order to respond to the needs of the learners. We adopted a dialectic approach in order to analyse the School Management Teams understanding of assets, that is, we looked at each picture and text closely and then the classification of pictures and texts. We then drew meanings from their discussions.

\section{Three 'Tiers' of Community Assets}

In presenting and discussing the School Management Teams' understanding of assets, the researchers adopted Mourad and Ways'
(1998) classification of community assets. These authors describe three different components of community assets and their significance to the well-being of that community. The three tiers of community assets namely; primary (the most immediate to a community), secondary (the less immediate) and outside tiers (those outside the immediate community) simply identify assets that are available to the community from an inside-outside approach. Mourad and Ways (1998) depict beautifully that an inside-outside asset mapping is necessary for the sustenance and well-being of all humankind as it foregrounds inner strengths, intrapersonal relationships and people's inner abilities.

\section{Primary Tier}

In the case of this study, the most easily accessible primary tier assets are typically those that are located within the school. In this regard, the School Management Teams identified teachers, learners, class managers, the deputy principal and school infrastructure.

What emerges is that each school boasts a unique combination of assets upon which to build the future of all children. In teachers, learners and school infrastructure, one can discover a vast and often surprising array of individual talents and productive skills. In this regard, the School Management Teams gave plausible explanations of their collage as testified by some of their responses below. Lungi had the following to say:

I have included learners in my collage...let learners tell their stories. My point is that we might end up with some of the learners coming out to talk about their own experiences, help to address problems.

Janny responded: They can be bold to come and share their experience.

The School Management Teams agreed that learners might be valuable assets to address their own vulnerability. This suggested that the School Management Teams understood learners as partners in support of other learners orphaned and made vulnerable due to HIV and AIDS. The School Management Teams explained that involving learners as assets would perhaps provide a glimpse into the children's world.

In their collage School Management Team members also positioned educators and the dep- 
uty principal as some of the crucial resources available to address the needs of orphaned and vulnerable children. The data from the explanation of their collage revealed that educators acted with compassion to try to address the issues of orphaned and vulnerable children in the schools. Here is what some of them had to say:

Janny: At school we (teachers) initiated a drop-in-centre where learners can come and eat'.

Lungi: We asked for the principal's assistance in identifying people whom we can approach for this drop-incentre'.

Muzi: $\quad$ Sometimes when I am eating, maybe I will eat half and then leave the other half for the boy in Grade 12 because I've been to his home at one stage and know the situation. Some teachers buy them uniforms; others will even go as far as paying their school fees.

Bhana et al. (2006) also found that teachers particularly those in rural schools do provide basic care for orphaned and vulnerable children but indicate that these teachers often lack adequate skills to fully provide the necessary support. In this regard, the School Management Teams explained that teachers needed training.

It appeared to the researchers that there were clear opportunities to promote initiatives that would benefit orphans and other children made vulnerable by AIDS in the context of existing efforts, but there seemed to be a need for strengthening school systems to be more focused and to work as a team. Typically, stronger links between the constituents might result in orphaned and vulnerable children having healthier and more positive relationships. Cook and Du Toit (2005) explain that the relationships, when optimal, have the potential to foster positive self-esteem and powerful identities.

\section{Secondary Tier}

A close examination of both the School Management Teams' collage and the discussions held during the creation of the collage revealed the next 'tier' of assets as being located inside the neighbourhood but not controlled by the school. This is also consistent with Mourad and Ways' (1998) classification we described above. In this regard, the School Management Teams identi- fied community members (no special names were given); faith-based organizations; and the Centre for the AIDS Programme of Research in South Africa as important assets.

Local neighbourhood associations and organisations are central to the survival of the school. These may be formal or informal and could include cultural groups, faith-based organisations, small businesses, support groups and recreation centres (Khanare 2008). The School Management Team participants explained the choices of their assets as follows:

Lungi: There are also fertilizer and plants for parents especially those who are not working to do some ploughing. Saby (Indian businessman) has promised to come to our school and train learners together with their parents. Parents are now attending farming classes.

Lungi: We talked with the principal about whether we can invite Centre for the AIDS Programme of Research in South Africa team to come to our school.

Muzi: Yah! There are some companies which are willing to assist, some company was going to give our school Christmas gifts but we could not get those because we are too far from town, we did not have transport.

Activities related to care and support of orphaned and vulnerable children are becoming more critical in the schools as the number of children who are orphaned and those made vulnerable by HIV and AIDS, care for their ill parents and/or siblings (Kartell and Chabilall 2005) is increasing. Mourad and Ways (1998) contend that an asset-building initiative must reintegrate the resources of local organisations into the school community development activities. In most cases, the depth and extent of associational life in any community is vastly underestimated (Kretzmann and McKnight 1993). This is particularly true in 'rural' and 'poor' communities, however, these groups are indispensable tools for the development and many of them can in fact be stretched beyond their capacities and intentions to become full contributors to the welfare of orphaned and vulnerable children (Kretzmann and McKnight 1993). The School Management Teams' leadership should be in a position to network with the local associations and other institutions in terms of local investments. 


\section{An 'Outside' Tier}

The last accessible assets from the School Management Teams' collage were those from 'outside' the community, both in location and ownership. According to Mourad and Ways (1998), this tier includes but is not limited to private businesses; national corporations; and non-governmental organisations. In this category, the School Management Teams identified the Child Welfare Department; 'Municipalities'; and 'Pickn' Pay' Supermarkets.

While the School Management Teams seemed to have little knowledge about specific strategies to harness and map resources available to the school in relation to orphaned and vulnerable children, they were able to identify other resources that could be drawn from. They suggested the need for collaborating with other community organisations and government sectors. The importance of pulling resources together was evident in the School Management Teams' collage discussion, as indicated below:

Lungi: We organize social worker to the school and help with birth certificates."

Janny: The other thing is, one of the ladies from the Municipality in Pietermaritzburg came to our school and she is willing to help parents or guardians of these learners.

Janny: What we are actually saying here is that, the school should work with other government departments.

The School Management Teams' realisation of the need to work together with other stakeholders in addressing the needs of orphaned and vulnerable children is shared by others. The Department of Education (2003) indicated that the school alone cannot cope with caring for and support of orphaned and vulnerable children. Circles of Care (Cook and Du Toit 2005) emphasises the importance of connectedness, participation and strategic partnership as an effective strategy for overcoming orphaned and vulnerable children challenges. This is in keeping with the Education White Paper 6 (DoE 2001) and Bronfenbrenner's (1979) holistic, systematic and inclusive support to respond to children's issues.

In the preceding sections, the researchers primarily showed the School Management Teams' conceptualisation of assets that they could draw from in order to address issues of orphaned and vulnerable children in their school context. The focus has been to explore the School Management Teams understanding of assets from an inside-outside or asset-based approach as opposed to outside-inside or need-based model. The School Management Teams' inventory of assets generally fell into three categories: individuals, associations and institutions (Ebersohn and Eloff 2006). School Management Team members weaved the strands of support together in various patterns including the need for stable relationships, proper nutrition, good health, and partnership with local communities and other government departments. The School Management Teams were able to identify assets of community, family, society, schools and individuals.

In the next section the researchers reflect on how collage as a visual participatory method enabled School Management Team members to identify assets available to the school.

\section{Enabling the Voice through Collage}

Collage provides an opportunity for the participants to play an active role in the generation of data. The incorporation of participants towards a collaborative and participative way of doing research highlights the view that even in remote contexts such as rural areas people do not have to live in isolation. Prosser (2008: 14) is of the view that: "visual researchers choose to place their metaphorical fulcrum...closer to collaborating 'with' respondents and seeing them as experts in their own lives."

By literally placing magazines, scissors, glue, charts at the disposal of the School Management Teams, the 'wow', 'stare', 'touch', and 'huh' moments began and there was a shift from a researcher-centric construction of the social world to that of participants as experts of their own lives. In contrast to the orthodox interview and observation methods, collage adds focus to a phenomenon (in this case orphaned and vulnerable children) under investigation.

\section{Connectedness among Participants}

Collage as a visual participatory technique enabled or evoked a sense of both collective and personal knowledge. It is said that collage is ambiguous and therefore requires the con- 
textual and participative engagement of participants which comes in the form of working together. In line with this, Irwin (2003: 9) explains "the collage-making process inherently uses metaphor metonymy and ...challenges the dichotomy of the intellect and senses." This brings us to the relevance of the collage as a 'capacity focused alternative' as expressed by the following participants:

Muzi: Yah! I think we need refresher courses for the teachers to be re-trained so that they can be able to deal with HIV and AIDS-related issues andorphaned and vulnerable children.

Busi: Yah! That refresher course is a good point, write it down.

Lungi: Oh! And I think we should write an explanation why we need a refresher course. Please write HIV testing so that we do not forget.

Nay: Remember you have to put that in your collage.

Janny: How do we paste, I mean the direction of the pictures.

Lungi: They should face one side in an order.

The quotes above confirm the view that "there is basic truth that every individual has something to contribute, even though it may not be mobilized yet" (Ebersohn and Eloff 2006: 151). In this respect, issues of orphaned and vulnerable children would cease to be seen as a burden for certain individuals or schools, but as having the potential to create synergies that harness more people. Collage contributes to 'greater levels of expression, and in turn greater areas for examination and subsequent clarification (William 2000: 275). This study's findings with the School Management Teams are consistent with William's observation here.

The researchers found that through collage the School Management Teams felt less pressured than otherwise in the course of discussing sensitive issues such as HIV and AIDS and orphaned and vulnerable children. Participants did not have to speak directly about the sensitive and difficult issues but went through a material 'go-between' (for example, cutting pictures, classifying pictures and texts and pasting on the chart). Thus, the ambiguity of collage provided a way of expressing the said and unsaid through text and pictures. Therefore in its sophisticated form collage dissolves the traditional or orthodox approach of doing research.

\section{Kaleidoscopic Representation of School Assets in Response to Orphaned and Vulnerable Children}

In its simplest form, collage is a process that involves reasoning and where ideas are shared, challenged and debated. In this case as the School Management Teams 'cut' and 'paste', conversations occurred via an iterative process. Below are examples of the School Management Teams' sharing of ideas through collage:

Lungi: I have already taken down some points and ideas that we can use but I will read them to you. Ei! I'm not sure, but I have written the word 'informing' heh! Informing learners and community about orphaned and vulnerable children.

Janny: How?

Muzi: It's like eh! We are conscietising them, isn't that so?

Janny: The question is, when do we make them participate in finding solutions to the needs of Orphaned and vulnerable children?

Evidence suggests that the position and capacity of the School Management Teams, through the medium of collage, led members to re-conceptualise issues of orphaned and vulnerable childrenas a broader development issue of focus. The collage depicts the participants' responses based on creating networks to use available capacity more effectively. The following excerpts illustrate this point.

Muzi: Finding solutions about how to support orphaned and vulnerable children is not the work of teachers alone, learners do support each other, we need to challenge them so that they come up with possible solutions, just to make them part of the whole thing.

Lungi: The peer educators are helpful (write them down) because they get trained and then they come back to school and then these learners get back and start teaching other learners how to be motivated and be strong. Orphaned and vulnerable children do not only need food or clothes but motivation too.

Janny: So, what do we write here? 
Lungi: I think we should write 'surviving skills.

Muzi: Please write 'be informed' for me there, near that picture and motivation, there.

Janny: So, I think we can make a list of all orphaned and vulnerable children... those who do not have Birth Certificates...those who need social grants and organise a social worker for them.... we make sure that help comes to the school so that learners do not go and stand in long queues applying for identity documents and miss out their studies.

Janny: Write Pick ' $n$ Pay there. We asked Pick ' $n$ Pay to give us their left 'overs'...so that we can give them to the learners and we found that they had lots of food to give.

Lungi: Enough about the food issue, we need to look at other solutions, and I also talked about the issue of clothes and shoes in that teachers also try and bring old things from home... sometimes approach companies for school uniforms.

Janny: Ok! Let's look for pictures then.

As the researchers pointed out earlier, School Management Teams did not just go into the "cut and paste' activity. Instead they were forced to recall and re-look what is going on in their schools as far as orphaned and vulnerable children issues are concerned. This collage work is also linked to David Ausubel's cognitive theories, also known as assimilation where there is an emphasis on the significance of prior knowledge in being able to learn new concepts and ideas (Prosser 2008: 20). Therefore, asset mapping through collage created a space for multiple voices and interpretations. It also forced in a positive way the School Management Teams to articulate their perceptions, engage in reflections, and generate and communicate about the range of assets available to addressing the issues of orphaned and vulnerable children in their school. Collage also acted as a diagnostic tool for both the School Management Teams' and schools' actions as well as an aid to mapping and mobilising assets to effectively address issues of orphaned and vulnerable children. We also argue that the collage approach is premised on a constructivist notion of learning which al- lowed the School Management Teams to frame their understanding of new knowledge on the basis of existing beliefs or notions.

\section{Creativity and Agency}

Visual research provides an insight into visual texts and sign systems that communicate cultural or other significant information about society and individuals. Creativity is non-monolithic (Butler-Kisber 2008) but takes many forms and contributes to empirical studies in multiple ways. In this paper we extend the participatory principle by emphasising participants' ownership and agency as they charted their way forward in trying to address the issues of orphaned and vulnerable children in their school. The following comments attest to this:

Nay: I was going to ask something, does this stop here because that's fine for our research? How could we use this next year?

Muzi: Yah! I think it is important information worth sharing, especially what I have learnt today, it's a lot, I think it's something that can be shared with my school as well. This activity was challenging to me, you actually opened our eyes, thank you for that. I need to go back to my school and share with teachers before I move to another school.

The researchers argue that collage was a successful pedagogical tool that the School Management Teams as members of the school community employed in order to identify, map and mobilise assets that were available to them. The complexities of HIV and AIDS matters and that of care and support of orphaned and vulnerable children have led to a change in ways of communication. Consequently, researchers have embarked on various and novel ways of addressing society's complex issues. Methodologically different from text-only approaches, collage as a visual participatory method provides access to qualities of life that literal language has no greater power to disclose (Butler-Kisber 2008).

\section{CONCLUSION}

The study the researchers have reported on in this article sought to explore School Management Teams' understanding of assets that could 
be used to address orphaned and vulnerable children's needs and to examine the efficacy of utilizing collage as a visual participatory approach in this regard. This study positioned the School Management Team as a crucial leadership structure in every South African public school, particularly in the context of HIV and AIDS. Such leadership is even more crucial in rural contexts where isolation, poverty, lack of resources and the attendant feelings of hopelessness tend to dominate people's lives.

The researchers conclude that the School Management Teams demonstrated deep understandings of assets that could be brought to bear in addressing orphaned and vulnerable children needs. Their construction of assets as generally classified into three tiers: primary, secondary and outer ones, was consistent with the literature the researchers found. The researchers are convinced that the School Management Teams' understandings reveal the importance of the asset-based approach in turning around the fortunes of organisations. Even in the poor, rural context of the schools we studied, useful assets were identifiable and their utility discussed and determined. This sentiment can best be described by what one of the School Management Team members had to say during the course of constructing the collage:

... right now we have been talking about 'hand-outs', that is good on one side but I think in a way there must be a way to train or help these people to help themselves, rather than depending on other people, because now it's becoming like a culture, especially in our country because we expect that people will be given things. It's good though because there are centres that provide but I think in schools we should encourage may be things like internships (write it down in our collage) whereby, we can teach them those skills, for them to be able to make a living, I think we actually do need it.

The findings of this study suggest that the often observed pathological behaviour, where people are seen or see themselves merely as 'needy', the deficit approach, has been overtaken by the asset-based model, which affirms, acknowledges and embraces the assets, gifts, and capacities in people, in the case of this paper, of schools situated in 'poor' communities. Deficit thinking is a tired approach and therefore it should be retired. However, focusing on the assets of lower income communities such as rural schools does not imply that those communities do not need additional resources from outside. Rather, such communities should be mobilized to define their own agendas for which additional resources can be obtained. This strong internal focus is intended simply to stress the creativity, hope and control of communities' own challenges and resources to solve those problems. An important implication of the asset-based approach is that effective leadership should be devised to mobilise and build the assets and also strengthen relationships.

The researchers also conclude that the constructivist nature of collage as a visual participatory method has demonstrated ability to provide participants with new experiences and different ways of thinking about the phenomenon at stake. Through collage the School Management Teams revealed aspects about their everyday life with orphaned and vulnerable children in school the context that might not have surfaced through other methods. This medium enabled School Management Team members to cast their opinions about assets available to the school in order to respond to issues of orphaned and vulnerable children, stir up discussion in the data generation sessions where reflective questioning by the researcher and the participants was framed around the collage images and texts in order to clarify relationships, significance of issues presented, personal feelings, and values of these to the schools as centres of care and support of orphaned and vulnerable children. Using collage as a product, school communities could also identify their weaknesses and eyesores, which could be subsequently eliminated or transformed into strengths and assets to effectively address issues including those of orphaned and vulnerable children. Of course, further in the future, a school community might even have to look for more connections in order to muster more the support necessary for orphans and other children made vulnerable by AIDS. The importance of sound leadership in efforts to apply the asset-based approach cannot be over-emphasised.

\section{REFERENCES}

Abdool-Karim SS 2006. The State of HIV Epidemic in South Africa. From <http: //www.phru.co.za/pact/ 
pact2006/s!_p2.pdf> (Retrieved October 11, $2011)$.

Al-Barwani T, Osman ME 2011. Promoting students learning through sustainable innovations: Where is the missing link? In: T Townsend, J MacBeath (Eds.): International Handbook of Leadership for Learning. London and New York: Springer, pp. 845-866.

Allnutt S, Mitchell C, Stuart J 2007. The visual archive: Uses and interruptions. In: $\mathrm{N}$ De Lange, $\mathrm{C}$ Mitchell, J Stuart (Eds.): Putting People in the Picture. Amsterdam: Sense, pp. 89-100.

Argall J, Allemano E 2009. Schools as Centres of Care and Support: Responding to the Needs of Orphans and Other Vulnerable Children in Rural Area. From <http: //www.communit.com/en/node/ 325385/38> (Retrieved October 23, 2011).

Babbie E, Mouton J 2009. The Practice of Social Research. Cape Town: Oxford University Press.

Balfour RJ, Mitchell C, Moletsane R 2008. Troubling contexts: Towards a generative theory of rurality as educational research. Journal of Rural and Community Development, 3(3): 95-107.

Becker HS 1974.Photography and sociology.Studies in Visual Anthropology of Visual Communication, 1(1): 3-26.

Bhana D, Morrell R, Epstein D, Moletsane R 2006. The hidden work of caring: Teachers and the maturing AIDS epidemic in diverse secondary schools in Durban. Journal of Education, 38: 5-24.

Bronfenbrenner U 1979. The Ecology of Human Development: Experiments by Nature and Design.Cambidge, MA: Harvard University Press.

Butler-Kisber L 2008. Collage as inquiry. In: JG Knowles, AL Cole (Eds.): Handbook of the Arts in Qualitative Research. Thousand Oaks, CA: Sage Publications, pp. 265-276.

Buthelezi T 2008.Providing leadership for managing HIV and AIDS in schools. In: L Wood (Ed.): Dealing with HIV and AIDS in the Classroom. Cape Town: Juta and Company Limited, pp. 108-127.

Chikoko V 2008. Developing teachers for rural education? Reflecting on the $2^{\text {nd }}$ KwaZulu-Natal Department of Education.Perspectives in Education, 26(4): 74-85

Collier J, Collier M 1986. Visual Anthropology: Photography as a Research Method. Albuquerque: University of New Mexico Press.

Cook P, Du Toit L 2005. Overcoming Adversity with Children Affected by HIV/AIDS in the Indegeneous South African Cultural Context. From <http: //web.uric.ca/iicrd/pub_report.html> (Retrieved October 10, 2011).

Creswell JW 1994. Research Design: Qualitative and Quantitative Approaches. London: SAGE Publications.

Department of Basic Education and MIET Africa 2010.National Support Pack. Durban: MIET Africa.

Department of Education 2003.Develop an HIV and AIDS Plan for your School: A Guide for School Governing Bodies and Management Teams. Pretoria: Government Printers.

Department of Education 2001.National Policy on HIV/ AIDS for Learners and Educators in Public Schools and Students in Further Education and Training Institutions. Pretoria: Government Printers.

Department of Basic Education 1996.Changing Management to Manage Change in Education:Report of the Task Team on Education Management Development. Pretoria: Government Printers.

Ebersohn L, Eloff I 2006. Identifying asset-based trends in suitable programmes which support vulnerable children. SAJE, 26(3): 457- 472.

Fargas-Malet M, McSherry D, Larkin E, Robinson C 2010. Research with children: Methodological issues and innovative techniques. Journal of Early Childhood Research, 8(2): 175-192.

Gabela RV 2006.Unpublished Opening Remarks at the $2^{\text {nd }}$ KwaZulu-Natal Department of Education Teacher Development Conference. University of KwaZulu-Natal: Pinetown.

Goffman E 1979. Gender Advertisements. New York: Harper and Row. From <http: //www.sociology.org/ content/vol002.001/smith.html> (Retrieved November 11,2011 ).

Irwin R 2003. Toward an aesthetic of unfolding in/ sights through curriculum.Journal of the Canadian Association for Curriculum Studies, 1(2): 6378.

Kartell C, Chabilall JA 2005. HIV/AIDS in South Africa: A study of the educational development of adolescents orphaned by AIDS in child-headed households. International Journal of Adolescence and Youth, 12(3): 213.

Kendall N 2007. Parental and community participation in involving educational quality in Africa: Current practices and future possibilities. International Review of Education, 53: 701-708.

Kendall N, O'Gara C 2007. Vulnerable children, communities and school: Lessons from three HIV/ AIDS-affected areas.Comapre, 27: 5-21.

Khanare F 2009. 'We are not alone": Taking an assetbased approach in responding to the needs of orphaned and vulnerable children. In: C Mitchell, K Pithouse (Eds.): Teaching and HIV and AIDS. Northlands: Macmillan, pp. 90-104.

Khanare FP 2008.School Management Teams'Response to Learners who are Orphaned and Vulnerable in the Context of HIV and AIDS: A Study of Two Rural Senior Secondary Schools in KwaZulu-Natal. M.Ed Dissertation, Unpublished. Pinetown: University of KwaZulu-Natal.

Kretzmann J, McKnight J 1993. Building Communities from the Inside-out: A Path toward Finding and Mobilizing Community Assets. Chicago: ACTA Publications.

Mitchell C, De Lange N, Stuart J, Moletsane R, Buthelezi T 2007. Children's provocative images of stigma, vulnerability and violence in the age of AIDS: Revisualisations of childhood. In: N De Lange, C Mitchell, J Stuart (Eds.): Putting People in the Picture: Visual Methodologies for Social Change. Rotterdam: Sense Publishers, pp. 59-72.

Mitchell C, De Lange N, Moletsane R, Stuart J, Buthelezi T 2005. The face of HIV and AIDS in rural South Africa: A case for photo-voice. Qualitative Research in Psychology, 3: 257-270.

Mourad M, Ways H 1998. Comprehensive Community Revitalization: Strategies for Asset Building. From 
< http: //design.asu.edu/apa/proceedings98/Mourad/ mourad.html/> (Retrieved March 18, 2009).

Mudaly R, Sookrajh R 2008. Young HIV and AIDS researchers-calling the gender shots through photovoice. Agenda, 75: 105-118.

$\mathrm{Ng}$ 'anjo M 2011. The role of citizen action in mitigating the negative impacts of HIV and AIDS. Government and AIDS Programme/IDASA, 1:1-6.

Norris G, Mbokazi T, Rorke F, Goba S, Mitchell C 2007. Where do we start? Using collage to explore very young adolescents' knowledge about HIV and AIDS in four senior primary classrooms in KwaZuluNatal. International Journal of Inclusive Education, 11(14): 481-499.

Olivier T, Wood L, De Lange N 2007. Changing our eyes: Seeing hope. In: N De Lange, C Mitchell, J Stuart (Eds.): Putting People in the Picture: Visual Methodologies for Social Change. Rotterdam: Sense Publishers, pp. 11-30.

Pansiri NO 2008. Improving commitment to basic education for the minorities in Botswana: A challenge for policy and practice. International Journal of Educational Development, 28(4): 446-459.

Park EG, Mitchell C, De Lange N 2007. Working with digital archives: Photovoice and meta analysis in the context of HIV and AIDS. In: N De Lange, C Mitchell, J Stuart (Eds.): Putting People in the Picture: Visual Methodologies for Social Change. Rotterdam: Sense Publishers, pp. 163-172.

Prosser J 2008. Introducing Visual Methods.ESRC National Centre for Research Methods. From <http:/ /eprints.ncrm.ac.uk/420/1/MethodsReviewPaperNCRM-010.pdf> (Retrieved November 04, 2011)

Prosser J 1998. Image-Based Research: A Sourcebook for Qualitative Researchers. From <http: // books.google.com/books? id=3d913psJ9s Candprintsec $=$ frontcoverand source $=$ gbs ge summar randcad $=0 \#>$ (Retrieved November 04, 2011)

Schley W, Schratz M 2011. Developing leaders, building networks, changing schools through system leadership. In: T Townsend, J McBeath (Eds.): International Handbook of Leadership for Learning. London: Springer, pp. 272-293.

Sullivan G 2010. Art Practice as Research: Inquiry in Visual Arts. Los Angels: SAGE.

Thomson P 2008. Children and young people: Voices in visual research. In: P Thomson (Ed.): Doing Visual Research with Children and Young People. London and New York: Routledge, pp. 1-20.

UNAIDS 2010a. Children and AIDS: Fifth Stocktaking Report. From <http: //www.unicef.org/publications/index_57005.html $>$ (Retrieved September 02,2011 )

UNAIDS 2010b.Country Progress Report on the Declaration of Commitment on HIV/AIDS. 2010 Report: From <http: //www.unicef.org/publications/ index_57005.html> (Retrieved September 02, $2011)$.

UNAIDS 2009.Global Facts and Figures. From <http: / /data.unaids.org/pub/Factsheet/2009/20091124_ fs_ global_en.pdf> (Retrieved October 23, 2010).

UNAIDS 2008. Report on the Global AIDS Epidemic. From <http: //www.unaids.org/en/dataanalysis/epidemiology/2008reportontheglobalaidsepidemic/> (Retrieved September 02, 2011).

UNICEF 2009.The State of World's Children Special Edition: Celebrating 20 years of the Convention on the Rights of the Child. New York: UNICEF.

Van Wyk N, Lemmer E 2007. Redefining home-based community in the context of HIV/AIDS pandemic.SAJE, 27(2): 301-316.

Wagner J 1979. Images of Information: Still Photography in the Social Sciences. Beverley Hills: SAGE Publications.

William SE 2010. Exploring the Viability of Schoolbased Support for Vulnerable: A Case Study of Two Township Schools in Johannesburg. Brighton: CREATE.

Williams B 2000. Collage work: A medium for guided reflection in clinical supervision. Nurse Education Today, 20(4): 273-280. 